\title{
Biogeographic evidence supports the Old Amazon hypothesis for the formation of the Amazon fluvial system
}

\author{
Karen Méndez-Camacho ${ }^{1}$, Omar Leon-Alvarado ${ }^{1,2}$, Daniel R Miranda-Esquivel ${ }^{\text {Corresp. } 1}$ \\ 1 Biology, Universidad Industrial de Santander, Bucaramanga, Santander, Colombia \\ 2 Programa de Pós-Graduação em Biodiversidade Animal, Universidade Federal de Santa Maria, Santa Maria, Rio Grande do Sul, Brazil \\ Corresponding Author: Daniel R Miranda-Esquivel \\ Email address: dmiranda@uis.edu.co
}

The Amazon has high biodiversity, which has been attributed to different geological events such as the formation of rivers. The Old and Young Amazon hypotheses have been proposed regarding the date of the formation of the Amazon basin. Different studies of historical biogeography support the Young Amazon model, however, most studies use secondary calibrations or are performed at the population level, preventing evaluation of a possible older formation of the Amazon basin. Here, we evaluated the fit of molecular phylogenetic and biogeographic data to previous models regarding the age of formation of the Amazon fluvial system. We reconstructed time-calibrated molecular phylogenies through Bayesian inference for six taxa belonging to Amphibia, Aves, Insecta and Mammalia, using both, nuclear and mitochondrial DNA sequence data and fossils as calibration points, and explored priors for both data sources. We detected the most plausible vicariant barriers for each phylogeny and performed an ancestral reconstruction analysis using areas bounded by major Amazonian rivers, and therefore, evaluated the effect of different dispersal rates over time based on geological and biogeographical information. The majority of the genes analyzed fit a relaxed clock model. The log normal distribution fits better and leads to more precise age estimations than the exponential distribution. The data suggested that the first dispersals to the Amazon basin occurred to Western Amazonia from 16.2-10.4 Ma, and the taxa covered most of the areas of the Amazon basin between 12.2-6.2 Ma. Additionally, regardless of the method, we obtained evidence for two rivers: Tocantins and Madeira, acting as vicariant barriers. Given the molecular and biogeographical analyses, we found that some taxa were fitted to the "Old Amazon" model. 
1 Biogeographic evidence supports the Old Amazon

2 hypothesis for the formation of the Amazon fluvial

3 system

Karen Andrea Méndez-Camacho ${ }^{1}$, Omar Daniel Leon-Alvarado ${ }^{1,2}$, Daniel Rafael Miranda-Esquivel ${ }^{1}$

${ }^{1}$ Laboratorio de Sistemática y Biogeografía, Universidad Industrial de Santander, Escuela de Biología, Bucaramanga, Santander, Colombia.

${ }^{2}$ Laboratorio de Sistematica, Entomología e Biogeografia, Universidade Federal de Santa Maria, Santa Maria, Rio Grande do Sul, Brasil.

Corresponding Author:

Daniel Rafael Miranda-Esquivel ${ }^{1}$

https://orcid.org/0000-0002-9913-7685

Cra 27 calle 9 UIS Edificio 35, Bucaramanga, Santander, 680002, Colombia

Email address: dmiranda@uis.edu.co

\section{Abstract}

The Amazon has high biodiversity, which has been attributed to different geological events such as the formation of rivers. The Old and Young Amazon hypotheses have been proposed regarding the date of the formation of the Amazon basin. Different studies of historical biogeography support the Young Amazon model, however, most studies use secondary calibrations or are performed at the population level, preventing evaluation of a possible older formation of the Amazon basin. Here, we evaluated the fit of molecular phylogenetic and biogeographic data to previous models regarding the age of formation of the Amazon fluvial system. We reconstructed time-calibrated molecular phylogenies through Bayesian inference for six taxa belonging to Amphibia, Aves, Insecta and Mammalia, using both, nuclear and mitochondrial DNA sequence data and fossils as calibration points, and explored priors for both data sources. We detected the most plausible vicariant barriers for each phylogeny and performed an ancestral reconstruction analysis using areas bounded by major Amazonian rivers, and therefore, evaluated the effect of different dispersal rates over time based on geological and biogeographical information. The majority of the genes analyzed fit a relaxed clock model. The log normal distribution fits better and leads to more precise age estimations than the exponential distribution. The data suggested that the first dispersals to the Amazon basin occurred to Western Amazonia from 16.2-10.4 Ma, and the taxa covered most of the areas of the Amazon basin between 12.2-6.2 Ma. Additionally, regardless of the method, we obtained evidence for two rivers: Tocantins and Madeira, acting as vicariant barriers. Given the molecular and biogeographical analyses, we found that some taxa were fitted to the "Old Amazon" model. 
44

45

46

47

48

49

50

51

52

53

54

55

56

57

58

59

60

61

62

63

64

65

66

67

68

69

70

71

72

73

74

75

76

77

78

79

80

81

82

83

84

85

86

87

88

\section{Introduction}

The Amazon basin harbors a high biodiversity, which has been attributed to different geological events such as the formation of rivers in a scenario that was proposed by Wallace (1852) known as the "riverine barrier hypothesis". Wallace's idea was formalized by Cracraft (1985) who presented a regionalization based on bird distributions and the major Amazonian rivers. Over the years this regionalization has changed based on updated information and methods (Silva, Novaes \& Oren, 2002; Borges \& Silva, 2012), providing evidence either supporting or rejecting the "riverine barrier hypothesis" (e.g. Hayes \& Sewlal, 2007; Maldonado-Coelho et al., 2013; d'Horta et al., 2013; Oliveira, Vasconcelos \& Santos, 2017), and even reconsidering the rivers as vicariant barriers (Pirani et al., 2019).

Likewise, over the years geological studies based on sedimentation, mineralogy, lithology, paleoenvironmental conditions and fossils (e.g. Hoorn et al., 1995, 2010, 2017; Wesselingh et al., 2002, 2006 Latrubesse et al., 2010; Antoine et al., 2013, 2016; Horbe et al., 2013; Matos-Maravi et al., 2013; Rossetti et al., 2015; Jaramillo et al., 2017) have been focused on the formation of the Amazonian basin, proposing two geological models: The "Old Amazon" and the "Young Amazon". In those studies the temporal range of the formation of the basin remains controversial, however it is clear the influence and importance of different geological events that shaped and contributed to the formation of the actual Amazon basin. The first important event was the gradual uplift of the Eastern Cordillera in the Central and Northern Andes, which caused the closure of the Western Andean Portal and created a watershed in the middle Miocene ( 16.1 - 12.4 Ma, Hoorn et al., 1993, 2010, 2017; Parra et al., 2009; Antoine et al., 2013, 2016; Jaramillo et al., 2017) known as the Pebas mega-wetland system (hereafter, PMWS). This watershed was located in the Western Amazonia and was connected to the Caribbean Sea and bounded by the Purus Arch on the east (Figueiredo et al., 2009; 2010). In the middle late Miocene, the PMWS disappeared (Wesselingh et al., 2002, 2006; Antoine et al., 2013, 2016; Jaramillo et al., 2017) due to the uplift of the Eastern Colombian Andes ( 15.0 - 3.0 Ma, Mora et al., 2008), and as consequence, the Vaupés Arch was drawn close to the Andes, causing the OrinocoAmazonas separation event (Olivares et al., 2013; Jaramillo et al., 2017) and gradually reducing the water flux towards the Caribbean (Lundberg et al., 1998). Finally, due to the subsidence of Purus Arch, the Amazonas river changed its primary westward flow into the Pacific Ocean to an eastward flow discharging into the Atlantic Ocean (Dobson, Dickens \& Rea, 2001; Figueiredo et al., 2009, 2010; Nogueira, Silveira \& Guimarães, 2013; Rosseti et al., 2015; Hoorn et al., 2017; van Soelen et al., 2017). Nevertheless, the dates when the Amazon River changes its flow and onset of the Amazon basin are still in debate, and are the main differences between the two geological models proposed. The "Old Amazon" model suggests that the fluvial system was established during the middle late Miocene ( 10.0 - 7.0 Ma, Hoorn et al., 1995, 2010, 2017; Figueiredo et al., 2009), while some authors consider an upper limit of $10.5 \mathrm{Ma}$ (Figueiredo et al., 2010), or even 14.0 Ma (Shephard et al., 2010). On the other hand, the "Young Amazon" model covers a wider temporal range, with studies agreeing that the basin was completely formed during the Pliocene-Pleistocene ( 2.5 Ma, Campbell, 
Frailey \& Romero-Pittman, 2006; Latrubesse et al., 2012 Rossetti et al., 2015). Both models have been evaluated using biogeographical qualitative (e.g. Ribas et al., 2012; Fernandes, Wink \& Aleixo, 2012) and quantitative (Quintero et al., 2015) approaches, which suggested that the Amazon basin was formed in the Pliocene-Pleistocene, agreeing with the "Young Amazon" geological model. These biogeographical studies also have found how some amazonian rivers influenced the evolutionary history of the species (e.g. Fernandes, Wink \& Aleixo, 2012; Alfaro et al., 2015), and established regions that matched with some main Amazonian rivers (Godinho \& da Silva, 2018; Vacher et al., 2020), providing more confirmatory evidence to the geological models of how the basin reached its current configuration.

The main idea in historical biogeography analyses is that geological events have influenced the diversification of the biota, and therefore this diversification pattern is seen in the phylogeny as common cladogenetic patterns, and from a Panbiogeographic point of view, those patterns from different taxonomic groups will agree, following Croizat's idea (1964) that the earth and its biota have evolved as a whole. The same idea is found in authors such as Cunningham \& Collins (1994), who proposed biogeographic congruence, namely, synchronous vicariant or dispersal events that reflect shared historical processes.

There are biogeographical studies that incorporate a big species sampling from a single group (Frogs or Birds, e.g. Santos et al., 2009; Smith et al., 2014), but few using species from different taxonomic groups. Also, most of the studies that have addressed the Amazon basin formation have used secondary calibrations (e.g. Buckner et al., 2015) —which increase uncertainty in age estimates (Schenk, 2016) - or are performed at the population level (e.g. Ribas et al., 2011), preventing evaluation of a possible older formation of the Amazon basin. Furthermore, the number of species used has been low in some studies (10-68\% less than the number of species used in the present study) (e.g. Pramuk et al., 2007; Maciel et al., 2010; Ramírez et al., 2010). Therefore, the goal of the present study is to evaluate the fit of molecular phylogenetic and biogeographic data to the previously described models ("Old" and "Young Amazon") regarding the age of formation of the Amazon fluvial system, using five hypotheses, varying the dispersal rates on different time scenarios.

\section{Materials \& Methods}

Selection of taxa. We selected taxa using the following criteria:

(1) We considered only monophyletic taxa with clades currently distributed in the Amazon basin;

(2) The phylogeny must include clades with divergence times covering the temporal ranges proposes by the two models (1.0-11.8 Ma, Hoorn et al., 2010; Figueiredo et al., 2009, 2010; Ribas et al., 2011);

(3) At least $60 \%$ of the described species in the phylogeny must have both mitochondrial and nuclear genes, and a minimum of three genes available at GenBank; (4) The taxa must have fossil records available in the literature for the ingroup or the outgroup (see Table S2), and the fossils must not have uncertain phylogenetic positions 
133 (Kay \& Meldrum, 1997; Kay \& Cozzuol, 2006; Hosner, Braun \& Kimball, 2016), or poor 134 stratigraphic information.

135

136

137

138

139

140

141

142

143

144

145

146

147

148

149

150

151

152

153

154

155

156

157

158

159

160

161

162

163

164

165

166

167

168

169

170

171

172

173

174

175

176

177

178

Molecular and Distributional data. We downloaded all nucleotide gene sequences available at GenBank for each taxon (see Data S1). Each gene was aligned separately using MUSCLE v3.8.31 (Edgar, 2004) with default settings. The nucleotide substitution models were selected with the Akaike Information Criterion (AIC, Akaike, 1974) with the modelTest function in the R package 'phangorn' v2.7.1 (Schliep, 2011). For the distributional data, we used the available literature and occurrences from the Global Biodiversity Information Facility (www.gbif.org, Table S1). The dataset was curated, removing points out of the known distributional range cited in literature.

Phylogenetic reconstruction. We carried out a Bayesian partitioned phylogenetic analysis as implemented in MrBayes v3.2.6 (Ronquist et al., 2012) via the CIPRES Science Gateway (Miller, Pfeiffer \& Schwartz, 2010). For each partition, we applied the nucleotide model previously selected, and tested whether the evolutionary rate was constant across the phylogeny (strict molecular clock) or it varies on each branch (relaxed molecular clock). Then, we chose the model that best fit our data through Bayes Factors (Kass \& Raftery, 1995). Once the evolutionary rate of the model was settled, we modelled the relaxed clock using the independent gamma rate model (Lepage et al., 2007; Bakiu, Korro \& Santovito, 2015), which is a continuous uncorrelated model of rate variation across lineages that assumes an independent rate on each branch following a gamma distribution. We used a fossilized birth-death process (Heath, Huelsenbeck \& Stadler, 2014; Zhang et al., 2016) to model the cladogenetic processes, taking into account speciation, extinction and fossilization.

Priors and clock dating. For each calibration point, we tested two informative prior distributions (exponential and log-normal) and chose the model that best fit the data through Bayes Factors (Kass \& Raftery, 1995). This step is crucial for the estimation of divergence times of the species. It has been proposed that the reason for overestimation of branch lengths is the poor choice of the prior distribution (Rannala, Zhu \& Yang, 2011). Both prior distributions differ in the location of the highest likelihood for the age of a node (Jones et al., 2013) and the parameters established for each one (Ho \& Philips, 2009; Arcila et al., 2015).

We conducted two independent runs with 30 million generations using the selected parameters, sampling every 2,000 generations and discarding the first $25 \%$ samples (burn-in). Each run consisted of four Metropolis-coupled Markov Monte Carlo chains with default temperatures ( $\Delta=0.09$ between heated chains). Each analysis was carried out until the average standard deviation of split frequencies was below 0.05 (Ronquist et al., 2012). The convergence between runs was assessed using the effective sample size as reported in Tracer v1.7 (Rambaut et al., 2018) and the potential scale reduction factor (Ronquist et al., 2012). We also used the command 'mcmcp data=no' to perform the analyses without data and sampled from the priors only (Ronquist et al., 2012), to evaluate the impact of including only the priors on ages and monophyly. 
179 Infinite sites. We plotted the posterior means of the divergence of each clade against 180 the $95 \%$ posterior confidence interval values (Cls: Yang \& Rannala, 2006) for each 181 phylogeny to evaluate the uncertainty source in posterior estimates of the divergence times, either by molecular or fossil sampling. The plot is based on the fact that even with infinitely long sequences, uncertainties will remain in the posterior time estimates because the posterior converges to a one-dimensional distribution (Yang \& Rannala, 2006).

186

187

188

Ancestral area inference. We reconstructed the ancestral distribution using areas bounded by major Amazonian rivers (Alfaro et al., 2015, Fig. S1), under the dispersalextinction-cladogenesis model (DEC: Ree et al., 2005; Ree \& Smith, 2008) as implemented in the R package 'BioGeoBEARS' v1.1.1 (Matzke, 2018).

We assessed five different biogeographic hypotheses, the base hypothesis $(\mathrm{H} 0)$ with a constant dispersal rate in which all areas have the same probability, and four stratified hypotheses with different dispersal rates over time (Ree \& Smith 2008), abruptly changing the dispersal rates along the time span, therefore, we can evaluate whether there are changes related to the time and distribution of the ancestral areas in a given temporal range, and if those changes are related to the ranges proposed for the formation of the Amazon basin:

199 (1) The "Young Amazon" hypothesis $(\mathrm{H} 1)$, in which the dispersal rates were low before 11.8 Ma (proposed lower limit, code as 0.25 ), then started to increase (code as 0.50 ) during the temporal range in which the Amazon system began forming (11.8-2.5 Ma), and the rates became maximal when the Amazon basin reached its current form and size (after $2.5 \mathrm{Ma}$, code as 1.0 ).

(2) The "Old Amazon" hypothesis $(\mathrm{H} 2)$, where rates were intermediate $(0.50)$, ranging from $10.0-7.0 \mathrm{Ma}$, suggesting that the system was mostly formed during this range, and the Amazon basin was completely established after 7.0 Ma (1.0).

(3) The Lineage Through Time (LTT) hypothesis (H3, Fig. S2), based on a lineagethrough-time plot for all taxa together, and assumed the rates were low until $17.0 \mathrm{Ma}$ (0.25) and became intermediate (0.50) where the PMWS existed between 17.0-10.0 $\mathrm{Ma}$, then, for the maximal rates (1.0) in the last $10.0 \mathrm{Ma}$ to the present, considering that the PMWS drained, and the Amazon basin reached its present form.

(4) The River hypothesis $(\mathrm{H} 4)$, where the rates were minimum until $10 \mathrm{Ma}(0.25)$, intermediate from 10.0-7.0 Ma (0.50) when the Amazon River flowed eastward, and the rates were minimum after $7.0 \mathrm{Ma}(0.25)$ when the Amazon basin was completed.

We used a log-likelihood difference of two units to compare the models (Edwards, 1992), and therefore define the best hypothesis.

Additionally, we used RASE v0.3-2 (Quintero et al., 2015) as a comparative and confirmatory analysis of BioGeoBEARS. We used the previously dated phylogeny, and transformed the occurrences into polygons using a Minimum Convex Polygon with the $R$ package 'adehabitatHR' v0.4.19 (Calenge, 2020). We ran RASE with 50,000 iterations and logged every 10 iterations. As RASE does not estimate ancestral areas, 
224 we focused on the direct visual congruence of the dispersal/expansion events between

225 RASE and BioGeoBEARS.

226

227

228

229

230

231

232

233

234

235

236

237

238

239

240

241

242

243

244

245

246

247

248

249

250

251

252

253

254

255

256

257

258

259

260

261

262

263

264

265

266

267

268

269

Isolation barriers inference. We determined the potential isolation barriers for each clade following Hovenkamp $(1997,2001)$, who suggested that the only evidence of a speciation process in a geographical context is the allopatric distributions. We used the Vicariance Inference Program (VIP: Arias, Szumik \& Goloboff, 2011) and the Geographically explicit Event Model (GEM: Arias 2017) for this analysis. These methods do not require predefined areas, so the percentage of vicariant events can be higher compared with other methods. For VIP, we used a grid sample of $0.25^{\circ}$ to minimize undersampling and low resolution, and we used a strict non-overlapping rule. For GEM, following a brief cost exploration, we settled the costs to 1 to the vicariance, and 1000 to the remaining events to maximize the number of vicariant events.

Congruence between events. To quantify the congruence, we relied on the approach presented by Cunningham \& Collins (1994). The use of different taxa reduces the possible bias that a single taxon could exhibit. We obtained the vicariant events associated with the formation of Amazonian rivers for each clade based on the position of the rivers and through the reconstruction of the ancestral distribution and the evaluation of the vicariant barriers based on grids, and therefore, we did not require prior assumptions of areas. We checked whether the same river could be assigned as a vicariant barrier for two or more taxa, while they shared similar divergence times for that event. The congruence was evaluated for each method separately. We evaluated whether our results are in concordance with the dates found by other biogeographic studies, and dates proposed by geological studies. Finally, we verified whether the two aforementioned methodological approaches showed potential congruent vicariant events associated with the Amazonian rivers.

A methodological workflow can be found in the supplemental information (Fig. S3). Also, all data and R-scripts implemented in this research, and the results are available at: https://github.com/karen9/Amazonia.

\section{Results}

Taxa and calibration points. The dataset was composed of six phylogenies representing four different taxonomic groups (Table 1). For most of the taxa analyzed in this study, there are no biogeographic studies evaluating the role of rivers as speciation barriers. However, for Cebidae, there are analyses regarding the Madeira (Buckner et al. 2015), Negro, Branco, Tapajos, Xingu and Tocantins rivers (Alfaro et al., 2015; Boubli et al., 2015). For mammals, we found fossil information for the ingroup, while for the remaining groups, we used the fossils that were available for the outgroup (Table S2).

Molecular clock. The strict molecular clock model was rejected for all genes (Table S3), except for the ATP7A and COI for Stenodermatinae (log-difference of three to five, Kass \& Raftery, 1995). We verified the individual topologies of each of the two genes to 
assess the overall impact of these genes, which fit a strict model based on the total evidence topology. We found that they produced unresolved topologies, therefore COI

272 did not present common nodes and ATP7A presented $2 \%$ common nodes with the total evidence topology. Nonetheless, removing the ATP7A and COI genes was not useful, as the removal resulted in a less resolved topology (50\% of common nodes) with lower Posterior Probabilities (hereafter, PP).

276

277

278

Prior and posterior estimates. The exponential and log-normal distributions generated the same topology, but differed in branch lengths. All calibration points for each

279 phylogeny fit best to a log-normal distribution, showing the narrowest $95 \% \mathrm{Cls}$ without divergence date estimates (Fig. 1). Furthermore, the majority of the calibration points overlapped between the prior and the posterior distributions. For 16 calibration points, the prior overlapped with the posterior about $80-100 \%$, and for nine of these 16 calibration points, the posterior was narrower (Fig. 2).

The only exception in which the prior and the posterior did not overlap was Pampamys emmonsae Verzi, Vucetich \& Montalvo, 1995 (Echimyidae), where the posterior distribution was older with a difference of 3.0 Ma (median: 17.58, Cl-95\%: 21.58 - 14.09 Ma. Fig. 2). The absence of this fossil in the analysis led to a wider $95 \% \mathrm{Cl}$ (median: 18.84, Cl-95\%:23.35 - $14.68 \mathrm{Ma}$ ) than the analysis including it, with a difference of circa 1 Million years. However, the PP did not change between both analyses (100\%). On the other hand, the incorporation of the new fossil record in the Cebuella Gray, 1870 lineage (Cebidae) led to a narrower $95 \% \mathrm{Cl}(10.0-10.9 \mathrm{Ma})$ and a higher PP (100\%) than the analysis without this calibration point (Cl-95\%: $8.7-4.5 \mathrm{Ma}$, and PP: $73 \%$ ).

294

295

Both, the posterior age means and the Cls fit best to a straight line under the

296

297

298

299

300

301

302

303

304

305

306

307

308 exponential fossil prior distribution (gray, Fig. 1), and led to older ages and a larger $95 \%$ Cls than the log-normal distribution (red, Fig. 1). The taxa with the oldest ages and the widest Cls (lower precision) in decreasing order were Melipona, Cracidae and Rhinella. The taxon with the most recent age and highest precision was Cebidae (Fig. 2).

Finally, the analyses using only priors resulted in unresolved topologies (results not shown), although monophyly was enforced on the calibrated nodes (nodes constrained by fossil ages).

Ancestral reconstruction. Dispersal is the main driver of most cases of speciation (Fig. 3), and the events reconstructed using BioGeoBEARS are concordant with dates proposed by Ribas et al. (2012). Although all taxa fit stratified models, four were better fitted to more than one stratified model, with a log-likelihood difference of $0.1-0.77$ 309 (Table S4). Cracidae and Stenodermatinae were the only two taxa that fit the "Young 310 Amazon" model, while the rest of the taxa fit the "Old Amazon " model (Fig. 3). For these two taxa, the first dispersal to the Amazon basin occurred from the Andes, in a temporal range of $\sim 3.0 \mathrm{Ma}(\mathrm{Cl}-95 \%: 0.99)$ for Cracidae, and $\sim 7.0 \mathrm{Ma}(\mathrm{Cl}-95 \%: 3.3)$ for Stenodermatinae (Fig. 3). On the other hand, for Rhinella, Echimyidae and Cebidae, the first dispersal to the Amazon basin occurred from the Atlantic Forest to some areas of the Western Amazonia (Napo, Marañon, and Ucayali) in the range of $16.2-10.4 \mathrm{Ma}$ 
316 (Fig. 3). Nevertheless, for Cebidae and Echimyidae, the first dispersal involved all areas

317

318

319

320

321

322

323

324

325

326

327

328

329

330

331

332

333

334

335

336

337

338

339

340

341

342

343

344

345

346

347

348

349

350

351

352

353

354

355

356

357

358

359

360

361 of the Amazon basin, then experienced a contraction of the ancestral range to the Atlantic Forest and the Andes, but there was no congruence in the temporal range in which these events took place (Fig. 3). Finally, Melipona presented both, the Andes and the Atlantic Forest as ancestral area, specifically, has one clade from the Andes and another from the Atlantic Forest, however, the dispersions through the Amazon basin for both clades occurred about $15.0-9.0 \mathrm{Ma}$ (Fig. 3), fitting the "Old Amazon" model.

With RASE we found similar results to those of BioGeoBEARS, nevertheless given the approach of RASE, we were not able to find the vicariant and contraction events, found with BioGeoBEARS, VIP and GEM (see below). Here, both Cracidae and Stenodermatinae started their dispersion from the Andes through the Amazon basin about $\sim 5.0-3.0 \mathrm{Ma}$ (Fig. 4). For Rhinella, Echimyidae and Cebidae the dispersion started circa $\sim 10.0 \mathrm{Ma}$ being more notorious at $\sim 7.0 \mathrm{Ma}$, and here, all dispersions started from the southern limit of the Amazonia basin (Fig. 4). For Melipona the dispersion dates were similar to those of Rhinella, Echimyidae and Cebidae, but they started from the northwestern part of the Amazon basin and the Andes (Fig. 4).

Isolation barriers and events. Both GEM and VIP recover more vicariant events than BioGeoBEARS, however, we only focused and reported those events that were congruent with BioGeoBEARS and could be associated with a river. We obtained nine vicariant events that might be associated with rivers (Fig. 5). From these events, three were congruent between GEM and BioGeoBEARS, and two between VIP and BioGeoBEARS, while the other four were congruent among the three methods (Fig. 5). Only the Madeira and Tocantins rivers were found as barriers from different taxa in similar time ranges. The Madeira River acted as a barrier for Cebidae and Melipona (Fig.5A, F) within $\sim 8.0-7.0 \mathrm{Ma}$. On the other hand, the Tocantins River acted as a barrier to Cebidae and Echimyidae (Fig. 5C, E) within the range $~ 8.0-7.0 \mathrm{Ma}$. Finally, we found the Amazon River as a possible barrier for three taxa: Cebidae, Cracidae, and Melipona (Fig. 5). Nevertheless, the dates of these events are not congruent ( 5,2 , and $10 \mathrm{Ma}$, respectively).

\section{Discussion}

Historical Amazon. We found that species dispersal agrees with a progressively developing Amazon drainage system from 16.2-10.4 Ma. We agree with Jaramillo et al., (2017) and recent literature (e.g. Antoine et al., 2016; Hoorn et al., 2017) that the PMWS was greatly reduced in the middle late Miocene. Moreover, we propose that the biota follow the development of the Amazon drainage basin, which, given the data, likely reached its shape and size from 12.2-6.2 Ma (Fig. 6C-D), when the taxa extended their distributions to Eastern Amazonia. In general, the temporal range found here agrees with the "Old Amazon" model, but we might consider a wider temporal range than those proposed by Hoorn et al. $(2010,2017)$.

Although both Cracidae and Stenodermatinae fit a stratified model of the "Young Amazon" hypothesis where the dispersal rates are maximum after $2.5 \mathrm{Ma}$, the

Peer) reviewing PDF | (2020:10:54082:2:0:NEW 23 Oct 2021) 
362 reconstruction of the ancestral range indicates a different scenario in which the first 363 dispersal to the Amazon basin occurred before $2.5 \mathrm{Ma}$, and occurred at different ranges 364 for each taxon. However, we cannot discard the possibility that after the first dispersal to 365 the basin, the number of dispersal events could have increased in response to the 366 complete establishment of this fluvial system.

The temporal range found here for the formation of the Amazon fluvial system agrees with the geological process sequence that occurred during that time. Hoorn et al. (1995, 2010) suggested that the formation of the Amazon River can be attributed to the Andean uplift, and our findings are consistent with stratigraphic studies regarding the emergence of the Eastern Cordillera of the Colombian Andes (Mora et al., 2008), and with paleobotanic observations, which suggest that elevations of the Eastern Colombian Andes were homogeneous between the early and middle Miocene and Pliocene (Gregory-Wodzicki, 2000), as well as with studies regarding the sedimentation rates of the Foz do Amazonas, which have highly increased since the middle Miocene (Figueiredo et al., 2009, 2010; Hoorn et al., 2017). On the other hand, our results are also congruent with other geological events, such as the date of activation of the Vaupés Arch in the Miocene (Jaramillo et al., 2017) and the subsidence of the Purus arch that allowed the Amazon to flow to the east. Although in the present study we can not establish the exact range of its subsidence, we can say that it might be assigned to the middle Miocene, which contrasts with other proposals (e.g. Nogueira et al., 2013). The geological events together have been broadly accepted as the main causes of the disappearance of the PMWS. Notwithstanding, our data and analyses do not allow us to establish the complete temporal range in which the system existed.

Our results are not affected by the number of time slices and different probabilities of dispersal in the range-inheritance scenarios (Ree \& Smith, 2008), and consequently, we cannot establish the temporal ranges in which there is a change in the dispersal rates according to the geological ranges proposed for the two aforementioned hypotheses. Moreover, using the biogeographical approaches we demonstrated that the large Amazonian rivers can limit species distribution ranges (Moraes et al., 2016; Oliveira, Vasconcelos \& Santos, 2017), while the dates found here differ from Ribas et al. (2011) and Alfaro et al. (2015) -which found events associated with the Tocantins river about 0.8-0.3 Ma, and Buckner et al. (2015), which found events for the Madeira river about 5 Ma-. It is worth noting that the methods used in this study to identify rivers as vicariant barriers are based on different algorithms, and therefore, different results could be expected. The main differences between our findings and those of other authors who tested or evaluated rivers as vicariant barriers are the type of analyses and the implemented data. Some studies have incorporated populations and species (Ribas et al., 2011; Buckner et al., 2015), while some only took into account mitochondrial genes (Alfaro et al., 2015) or secondary calibrations (Alfaro et al., 2015; Buckner et al., 2015) and did not carry out an exploration of priors.

During the last $20 \mathrm{Ma}$, the climate experienced drastic and rapid changes, ranging from warm to cool climate (Flower \& Kennett, 1993; Holbourn et al., 2015; Westerhold et al., 2020). These drastic changes directly affect the ecosystem, especially the plant 
408

409

410

411

412

413

414

415

416

417

418

419

420

421

422

423

424

425

426

427

428

429

430

431

432

433

434

435

436

437

438

439

440

441

442

443

444

445

446

447

448

449

450

451

452

community and may be a factor for the actual species distributions, especially for the dispersion event. Although climate and its effect on species distributions is clear, we do not have a compressive database to our time range to test the effects of climate on the dispersal events.

Ages estimates. The chosen priors are reasonable for modeling our data as there is a considerable overlap between the prior and the posterior density functions, with the posterior more concentrated than the prior (Fig. 2, Nascimento et al., 2017), but priors only do not determine the results. The infinite-sites plot (Fig. 1) suggests that the uncertainty in the posterior age estimates is mainly due to limited molecular data (Yang \& Rannala, 2006) and is not due to the fossil points used, as is reflected in the regression value, which is low in most cases (except for Cracidae).

We cannot rule out the possibility that both an increased density of taxon sampling at genome scale and fossil sampling could improve age estimates (Yang \& Rannala, 2006). We noted that incorporation of fossils for the clade in which posterior is older and out of the prior (e.g. Pampamys emmonsae) led to more precise age estimation (Foote et al., 1999; Smith \& Peterson, 2002; Sytsma, Spalink \& Berger, 2014).

The molecular clock model used here does not incorporate uneven fossil sampling (Drummond et al., 2012; Zhang et al., 2016), which could have impacted the posterior age estimates. Thus, the ancient and less precise ages produced in the present study could be due to a lack of internal node constraints, which leads to ancient ages (Bibi, 2013; Arcila et al., 2015). This could be highlighted by the fact that the taxon with most fossils (Cebidae) presents more precise date estimates for the entire dataset, and the amount of uncertainty added in the posterior $\mathrm{Cl}$ is lower (Fig. 1). On the other hand, in contrast with Heads (2012), our results show that the use of an exponential distribution for the calibration points generates older and less precise posterior estimates (Fig. 1), as was previously suggested (Heath, 2012; Sauquet et al., 2012; Arcila et al., 2015).

\section{Conclusions}

Our results provide support for the "Old Amazon" hypothesis, as well as for a middle late Miocene time origin for the Amazon drainage system. We only obtained evidence for the date of formation of two rivers (Tocantins and Madeira), although there might be other rivers acting as biogeographical barriers. For the temporal range studied here, the rivers did not structure the Amazonian biota. It is likely that there are other physical factors involved in Amazonian biota evolution, emphasizing the complexity and dynamics of the Amazonian system. It is, therefore, necessary to consider this issue with different tools with multiple sources of data. Furthermore, our analyses highlight the importance of including numerous fossil calibration points, distributed throughout the phylogeny, and an exploration of priors, resulting in more precise age estimates.

\section{Acknowledgements}


453 We thank Juan David Bayona-Serrano and Yelsin Méndez-Camacho, for their help 454 preparing the initial draft of the manuscript, to Daniel Pabón for advice and help in the 455 handling of supercomputing platforms, and all the members of the Laboratorio de 456 Sistemática y Biogeografía who contributed with feedback. We are grateful to Carina 457 Hoorn and Christine Meynard, which greatly improved the final version. Furthermore, we 458 thank the CIPRES facility for their available computational resources. D.R.M-E thank the 459 projects 8867: "Inventario de la diversidad biológica en una región del sur de Bolívar, 460 Colombia", and 8034: "Una expedición para reducir el déficit de conocimiento en 461 biodiversidad a una escala en Santander, Colombia". MinCiencias-Colombia/Vicerectoría 462 de Investigaciones UIS. 
464

465

466

467

468

469

470

471

472

473

474

475

476

477

478

479

480

481

482

483

484

485

486

487

488

489

490

491

492

493

494

495

496

497

498

499

500

501

502

503

504

505

506

507

508

\section{References}

Akaike H. 1974. A new look at the statistical model identification. IEEE Transactions on Automatic Control 19:716 - 723. DOI: 10. 1109/TAC. 1974. 1100705. Alfaro JWL, Boubli JP, Paim FP, Ribas CC, da Silva MNF, Messias MR, Rohe F, Merces MP, Júnior JSS, Silva CR, Pinho GM, Koshkarian G, Nguyen MTT, Harada ML, Rabelo RM, Queiroz HL, Alfaro ME, Farias IP. 2015. Biogeography of squirrel monkeys (genus Saimiri): South-central Amazon origin and rapid pan-Amazonian diversification of a lowland primate. Molecular Phylogenetics and Evolution 82:436 - 454. DOI: 10.1016/j.ympev. 2014.09.004.

Ali JR. 2012. Colonizing the Caribbean: is the GAARlandia land-bridge hypothesis gaining a foothold?. Journal of Biogeography 39:431 - 433. DOI: 10.1111/j. 1365-2699.2011.02674.x.

Antoine PO, Roddaz M, Brichau S, Louterbach M, Salas-Gismondi R, Altamirano A, Tejada J, Lambs L, Otto T, Brusset S. 2013. Middle Miocene vertebrates from the Amazonian Madre de Dios Subandean Zone, Perú. Journal of South American Earth Sciences 42:91 - 102. DOI: 10.1016/j.jsames.2012.07.008.

Antoine PO, Abello MA, Adnet S, Sierra AJA, Baby P, Billet G, Boivin M, Calderón Y, Candela A, Chabain J, Corfu F, Croft DA, Ganerød M, Jaramillo C, Klaus S, Marivauz L, Navarrete RE, Orliac MJ, Parra F, Pérez ME, Pujos F, Rage JC, Ravel A, Robinet C, Roddaz M, Tejada-Lara JV, Vélez-Juarbe J, Wesselingh FP, SalasGismondi R. 2016. A 60-millonyear Cenozoic history of western Amazonian ecosystems in Contamana eastern Peru. Gondwana Research 31:30 - 59. DOI:

10.1016/j.gr.2015.11.001.

Arcila D, Pyron RA, Tyler JC, Ortí G, Betancur-R R. 2015. An evaluation of fossil tip-dating versus node-age calibrations in tetraodontiform fishes (Teleostei:

Percomorphaceae). Molecular Phylogenetics and Evolution 82:131 - 145. DOI: 10.1016/j.ympev.2014.10.011

Arias JS, Szumik CA, Goloboff PA. 2011. Spatial analysis of vicariance: a method for using direct geographical information in historical biogeography. Cladistics 27:617 - 628. DOI: 10.1111/j.1096-0031.2011.00353.x.

Arias JS. 2017. An event model for phylogenetic biogeography using explicitly geographical ranges. Journal of Biogeography 44:2225 - 2235. DOI: 10.1111/jbi.13024.

Bacon CD, Silvestro D, Jaramillo C, Smith BT, Chakrabarty P, Antonelli A. 2015. Biological evidence supports an early and complex emergence of the Isthmus of Panama. Proceedings of the National Academy of Sciences 112:6110 - 6115. DOI: 10.1073/pnas.1423853112.

Bakiu R, Korro K, Santovito G. 2015. Positive selection effects on the biochemical properties of mammal pyroglutamylated RFamide peptide receptor (QRFPR). Italian Journal of Zoology 82:309 - 326. DOI:

10.1080/11250003.2015.1018352.

Bibi F. 2013. A multi-calibrated mitochondrial phylogeny of extant Bovidae (Artiodactyla, Ruminantia) and the importance of the fossil record to systematics. BMC Evolutionary Biology 13:166. DOI: 10.1186/1471-2148-13-166.

Peer) reviewing PDF | (2020:10:54082:2:0:NEW 23 Oct 2021) 
509

510

511

512

513

514

515

516

517

518

519

520

521

522

523

524

525

526

527

528

529

530

531

532

533

534

535

536

537

538

539

540

541

542

543

544

545

546

547

548

549

550

551

552

553

Borges SH \& Silva JMC. 2012. New Areas of Endemism for Amazonian Birds in the Rio Negro Basin. The Wilson Journal of Ornithology 124:15 - 23.

Boubli JP, Ribas C, Alfaro JWL, Alfaro ME, da Silva MNF, Pinho GM, Farias IP. 2015. Spatial and temporal patterns of diversification on the Amazon: a test of the riverine hypothesis for all diurnal primates of Rio Negro and Rio Branco in Brazil. Molecular Phylogenetics and Evolution 82:400 - 412. DOI:

10.1016/j.ympev.2014.09.005.

Buckner JC, Alfaro JWL, Rylands AB, Alfaro ME. 2015. Biogeography of the marmosets and tamarins (Callitrichidae). Molecular Phylogenetics and Evolution 82:413 - 425. DOI: 10.1016/j.ympev.2014.04.031.

Calenge C. 2020. adehabitatHR: Home Range Estimation, a collection of tools for estimation of animals home range. Available at https://cran. r-project.

org/web/packages/adehabitatHR/index. html

Campbell KE, Frailey CD, Romero-Pittman L. 2006. The Pan-Amazonian Ucayali Peneplain, late Neogene sedimentation in Amazonia, and the birth of the modern Amazon River System. Palaeogeography, Palaeoclimatology, Palaeoecology 239:166 219. DOI: 10.1016/j.palaeo.2006.01.020.

Cracraft J. 1985. Historical biogeography and patterns of differentiation within the South American avifauna: areas of endemism. Ornithological Monographs 36:49 - 84. DOI:10.2307/40168278

Croizat L. 1964. Space, Time, Form: the biological synthesis. Caracas: published by the author.

Cunningham C, Collin T. 1994. Developing model systems for molecular biogeography: vicariance and interchange in marine invertebrates. In: Schierwater B, Streit B, Wagner GP, DeSaller R. ed. Molecular Ecology and Evolution: Approaches and Applications. Experientia Supplementum. Basel: Birkhäuser, 405 - 433. DOI: 10.1007/978-3-0348-7527-1_24.

d'Horta FM, Cuervo AM, Ribas CC, Brumfield RT, Miyaki CY. 2013. Phylogeny and comparative phylogeography of Sclerurus (Aves: Furnariidae) reveal constant and cryptic diversification in an old radiation of rain forest understorey specialists. Journal of Biogeography 40:37 - 49. DOI: 10.1111/j. 365-2699.2012.02760.x.

Dobson DM, Dickens GR, Rea DK. 2001. Terrigenous sediment on Ceara Rise: a Cenozoic record of South American orogeny and erosion. Palaeogeography, Palaeoclimatology, Palaeoecology 165:215 - 229. DOI: 10.1016/S00310182(00)00161-9.

Drummond AJ, Suchard MA, Xie D, Rambaut A. 2012. Bayesian phylogenetics with BEAUti and the BEAST 1. 7. Molecular Biology and Evolution 29:1969-1973. DOI: 10.1093/molbev/mss075.

Edgar RC. 2004. MUSCLE: a multiple sequence alignment method with reduced time and space complexity. BMC Bioinformatics 5:113. DOI: 10.1186/1471-2105-5-113.

Edwards A. 1992. Likelihood. Baltimore: Johns Hopkins University Press.

Fernandes AM, Wink M, Aleixo A. 2012. Phylogeography of the chestnut-tailed antbird (Myrmeciza hemimelaena) clarifies the role of rivers in Amazonian biogeography. Journal of Biogeography 39:1524 - 1535. DOI: 10.1111/j.13652699.2012.02712.x. 
554

555

556

557

558

559

560

561

562

563

564

565

566

567

568

569

570

571

572

573

574

575

576

577

578

579

580

581

582

583

584

585

586

587

588

589

590

591

592

593

594

595

596

597

598

599

Figueiredo J, Hoorn C, Van der Ven P, Soares E. 2009. Late Miocene onset of the Amazon River and the Amazon deep-sea fan: Evidence from the Foz do Amazonas Basin. Geology 37: 619 - 622. DOI: 10.1130/G25567A.1.

Figueiredo J, Hoorn C, van der Ven P, Soares E. 2010. Late Miocene onset of the Amazon River and the Amazon deep-sea fan: Evidence from the Foz do Amazonas Basin: Reply. Geology 38:e213. DOI: 10.1130/G31057Y.1.

Flower BP, Kennett JP. 1993. The middle Miocene climatic transition: East Antartic ice sheet development, deep ocean circulation and global carbon cycling. Paleogeography. Paleoclimatology. Paleoecology 108: 537 - 555. DOI:10.1016/00310182(94)90251-8.

Foote M, Hunter JP, Janis CM, Sepkoski JJ. 1999. Evolutionary and preservational constraints on origins of biologic groups: divergence times of eutherian mammals. Science, 283:1310 - 1314. DOI: 10.1126/science.283.5406.1310.

Godinho MBC, da Silva FR. 2018. The influence of riverine barriers, climate, and topography of the biogeographic regionalization of Amazonian anurans. Scientific Reports 8:3427. DOI: 10.1038/s41598-018-21879-9.

Gregory-Wodzicki KM. 2000. Uplift history of the Central and Northern Andes: a review. Geological Society of America Bulletin 112:1091 - 1105. DOI: 10.1130/00167606(2000)112<1091:UHOTCA>2.0.CO;2.

Hayes FE, Sewlal JN. 2007. The Amazon River as a dispersal barrier to passerine birds: effects of river width, habitat and taxonomy. Journal of Biogeography 31:1809 - 1818. DOI:10.1111/j.1365-2699.2004.01139.x

Heads M. 2012. Bayesian transmogrification of clade divergence dates: a critique. Journal of Biogeography 39:1749 - 1756. DOI: 10.1111/j.13652699.2012.02784.x.

Heath TA. 2012. A hierarchical Bayesian model for calibrating estimates of species divergence times. Systematic Biology 61:793 - 809. DOI: 10.1093/sysbio/sys032.

Heath TA, Huelsenbeck JP, Stadler T. 2014. The fossilized birth-death process for coherent calibration of divergence-time estimates. Proceedings of the National Academy of Sciences 111:E2957 - E2966. DOI: 10.1073/pnas.1319091111.

Holbourn A, Kuhnt W, Kocchann KGD, Andersen Nils Meier KJS. 2015. Global perturbation of the carbon cycle at the onset of the Miocene Climatic Optimum. Geology 43:123 - 126. DOI: 10.1130/G36317.1.

Ho SY, Phillips MJ. 2009. Accounting for calibration uncertainty in phylogenetic estimation of evolutionary divergence times. Systematic Biology 58:367 - 380. DOI: 10.1093/sysbio/syp035.

Hoorn C. 1993. Marine incursions and the influence of Andean tectonics on the Miocene depositional history of northwestern Amazonia: results of a palynostratigraphic study. Palaeogeography, Palaeoclimatology, Palaeoecology 105:267 - 309. DOI: 10.1016/0031-0182(93)90087-Y.

Hoorn C, Guerrero J, Sarmiento GA, Lorente MA. 1995. Andean tectonics as a cause for changing drainage patterns in Miocene northern South America Geology 23:237 - 240. DOI: 10.1130/0091-7613(1995)023<0237:ATAACF>2.3.CO;2.

Hoorn C, Wesselingh F, Ter Steege H, Bermudez M, Mora A, Sevink J, Sanmartín I, Sanchez-Meseguer A, Anderson CL, Figueiredo JP, Jaramillo C, Riff D, 
600 Negri FR, Hooghiemstra H, Lundberg J, Stadler T, Särkinen T, Antonelli A. 2010.

601 Amazonia through time: Andean uplift, climate change, landscape evolution, and

602 biodiversity Science 330:927 - 931. DOI: 10.1126/science.1194585.

603

604

605

606

607

608

609

610

611

612

613

614

615

616

617

618

619

620

621

622

623

624

625

626

627

628

629

630

631

632

633

634

635

636

637

638

639

640

641

642

643

644 EL, Dino R, do Carmo DA, Chemale F. 2017. The Amazon at sea: Onset and stages of the Amazon River from a marine record, with special reference to Neogene plant turnover in the drainage basin. Global and Planetary Change 153:51-65. DOI: 10.1016/j.gloplacha.2017.02.005.

Horbe AMC, Motta MB, de Almeida CM, Dantas EL, Vieira LC. 2013. Provenance of Pliocene and recent sedimentary deposits in western Amazônia, Brazil: Consequences for the paleodrainage of the Solimões-Amazonas River. Sedimentary Geology 296:9 - 20. DOI: 10.1016/j.sedgeo.2013.07.007.

Horton BK. 2018. Tectonic regimes of the central and southern Andes: responses to variations in plate coupling during subduction. Tectonics 37:402 - 429 . DOI: $10.1002 / 2017$ TC004624.

Hosner PA, Braun EL, Kimball RT. 2016. Rapid and recent diversification of curassows, guans, and chachalacas (Galliformes: Cracidae) out of Mesoamerica: Phylogeny inferred from mitochondrial, intron, and ultraconserved element sequences. Molecular Phylogenetics and Evolution 102:320 - 330. DOI: 10.1016/j.ympev.2016.06.006.

Hovenkamp P. 1997. Vicariance events, not areas, should be used in biogeographical analysis Cladistics 13:67 - 79. DOI: 10.1006/clad.1997.0032.

Hovenkamp P. 2001. A direct method for the analysis of vicariance patterns. Cladistics 17:260 - 265. DOI: 10.1006/clad.2001.0176.

Jaramillo C, Romero I, D'Apolito C, Bayona G, Duarte E, Louwye S, Escobar J, Luque J, Carrillo-Briceño JD, Zapata V, Mora A, Schouten S, Zavada M, Harrington G, Ortiz J, Wesselingh FP. 2017. Miocene flooding events of western Amazonia. Science Advances 3:e1601693. DOI: 10.1126/sciadv.1601693.

Jones ME, Anderson CL, Hipsley CA, Muller J, Evans SE, Schoch RR. 2013. Integration of molecules and new fossils supports a Triassic origin for Lepidosauria (lizards, snakes, and tuatara). BMC Evolutionary Biology 13:208. DOI: 10.1186/14712148-13-208.

Kay RF, Meldrum J. 1997. A new small platyrrhine and the phylogenetic position of Callitrichinae. In: Kay RF, Madden RH, Cifelli RL, Flynn JJ, ed. Vertebrate paleontology in the Neotropics: the Miocene Fuana of La Venta, Colombia. Washington and London: Smithsonian Institution Press, 435 - 458.

Kass RE, Raftery AE. 1995. Bayes factors. Journal of the American statistical association 90:773 - 795. DOI: 10.1080/01621459.1995.10476572.

Kay RF, Cozzuol MA. 2006. New platyrrhine monkeys from the Solimões formation (late Miocene, Acre State, Brazil). Journal of Human Evolution 50:673 - 686. DOI: 10.1016/j.jhevol.2006.01.002.

Latrubesse EM, Cozzoul M, da Silva-Caminha SAF, Rigsby CA, Absy ML, Jaramillo C. 2010. The Late Miocene paleogeography of the Amazon Basin and the evolution of the Amazon River system. Earth-Science Reviews 99:99 - 124. DOI:10.1016/j.earscirev.2010.02.005. 
645

646

647

648

649

650

651

652

653

654

655

656

657

658

659

660

661

662

663

664

665

666

667

668

669

670

671

672

673

674

675

676

677

678

679

680

681

682

683

684

685

686

687

688

689

690
Lepage T, Bryant D, Philippe H, Lartillot N. 2007. A general comparison of relaxed molecular clock models. Molecular Biology and Evolution 24:2669 - 2680. DOI: 10.1093/molbev/msm193. 1

Lundberg JG, Marshall LG, Guerrero J, Horton B, Malabarba M, Wesselingh F. 1998. The stage for Neotropical fish diversification: a history of tropical South American rivers. Phylogeny and Classification of Neotropical Fishes 603:14 - 48.

Maciel NM, Collevatti RG, Colli GR, Schwartz EF. 2010. Late Miocene diversification and phylogenetic relationships of the huge toads in the Rhinella marina (Linnaeus, 1758) species group (Anura: Bufonidae). Molecular Phylogenetics and Evolution 57:787 - 797. DOI: 10.1016/j.ympev.2010.08.025.

Maldonado-Coelho M, Blake J, Silveira L, Batalha-Filho H, Ricklefs R. 2013. Rivers, refuges and population divergence of fire-eye antbirds (Pyriglena) in the Amazon Basin. Journal of Evolutionary Biology 26:1090 - 1107. DOI: 10.1111/jeb.12123.

Matos-Maravi PF, Pena C, Willmott KR, Freitas AV, Wahlberg N. 2013. Systematics and evolutionary history of butterflies in the "Taygetis clade" (Nymphalidae: Satyrinae: Euptychiina): Towards a better understanding of Neotropical biogeography. Molecular Phylogenetics and Evolution 66:54 - 68. DOI: 10.1016/j.ympev.2012.09.005. Matzke NJ. 2018. nmatzke/BioGeoBEARS: BioGeoBEARS: BioGeography with Bayesian (and likelihood) Evolutionary Analysis with R Scripts (Version v1.1.1). Zenodo. DOI: 10.5281/zenodo.1478250.

Miller MA, Pfeiffer W, Schwartz T. 2010. CIPRES Science Gateway. Available at: https://www. phylo. org.

Mora A, Parra M, Strecker MR, Sobel ER, Hooghiemstra H, Torres V, Jaramillo JV. 2008. Climatic forcing of asymmetric orogenic evolution in the Eastern Cordillera of Colombia. Geological Society of America Bulletin 120:930 - 949. DOI:

10.1130/B26186.1.

Moraes LJCL, Pavan D, Barros MC, Ribas CC. 2016. The combined influence of riverine barriers and flooding gradients on biogeographical patterns for amphibians and squamates in south-eastern Amazonia. Journal of Biogeography 43:2113 - 2124. DOI: 10.1111/jbi.12756.

Nascimento FF, dos Reis M, Yang Z. 2017. A biologist's guide to Bayesian phylogenetic analysis. Nature Ecology and Evolution 1:1446 - 1454. DOI: 10.1038/s41559-017-0280-x.

Nogueira ACR, Silveira R, Guimarães JTF. 2013. Neogene-Quaternary sedimentary and paleovegetation history of the eastern Solimões Basin, central Amazon region. Journal of South American Earth Sciences 46:89 - 99. DOI: 10.1016/j.jsames.2013.05.004.

Olivares AM, Hrbek T, Escobar MD, Caballero S. 2013. Population structure of the black Arowana (Osteoglossum ferreirai) in Brazil and Colombia: implications for its management. Conservation Genetics 14:695 - 703. DOI: 10. 1007/s10592-013-0463-1. Oliveira U, Vasconcelos MF, Santos AJ. 2017. Biogeography of Amazon birds: rivers limit species composition, but not areas of endemism. Scientific Reports 7:2992. DOI: 10.1038/s41598-017-03098-w.

Parra M, Mora A, Jaramillo C, Strecker MR, Sobel ER, Quiroz L, Rueda M, Torres V. 2009. Orogenic wedge advance in the northern Andes: evidence from the 
691 Oligocene- Miocene sedimentary record of the Medina Basin, Eastern Cordillera,

692 Colombia. GSA Bulletin 121:780 - 800. DOI: 10.1130/B26257.1.

693

694

Pirani RM, Werneck FP, Thomaz AT, Kenney ML, Sturaro MJ, Ávila-Pires TCS,

695

696

697

698

699

700

701

702

703

704

705

706

707

708

709

710

711

712

713

714

715

716

717

718

719

720

721

722

723

724

725

726

727

728

729

730

731

732

733 Peloso PLV, Rodrigues MT, Knowles MM. 2019. Testing main Amazonian rivers as barriers across time and space within widespread taxa. Journal of Biogeography 46:2444 - 2456. DOI: $10.1111 /$ jbi.13676

Pramuk JB, Robertson T, Sites JW, Noonan BP. 2007. Around the world in 10 million years: biogeography of the nearly cosmopolitan true toads (Anura: Bufonidae). Global Ecology and Biogeography 17:72 - 83. DOI: 10.1111/j.1466-8238.2007.00348.x.

Quintero I, Keil P, Jetz W, Crawford FW. 2015. Historical biogeography using species geographical ranges. Systematic Biology 64:1059 - 1073. DOI: 10.1093/sysbio/syv057.

Ramírez SR, Nieh JC, Quental TB, Roubik DW, Imperatriz-Fonseca VL, Pierce NE. 2010. A molecular phylogeny of the stingless bee genus Melipona (Hymenoptera: Apidae). Molecular Phylogenetics and Evolution 56:519 - 525. DOl:

10.1016/j.ympev.2010.04.026.

Rambaut A, Drummond AJ, Xie D, Baele G, Suchard MA. 2018. Posterior summarization in Bayesian Phylogenetics using Tracer 1.7. Systematic Biology 67:901 - 904. DOI: 10.1093/sysbio/syy032.

Rannala B, Zhu T, Yang Z. 2011. Tail paradox, partial identifiability, and influential priors in Bayesian branch length inference. Molecular Biology and Evolution 29:325 - 335. DOI: 10.1093/molbev/msr210.

R Core Team. 2020. R: A Language and Environment for Statistical Computing. Available at https://cran.r-project.org/.

Ree RH, Moore BR, Webb CO, Donoghue MJ. 2005. A likelihood framework for inferring the evolution of geographic range on phylogenetic trees. Evolution 59:22992311. DOI: 10.1111/j.0014-3820.2005.tb00940.x.

Ree $\mathrm{RH}$, Smith SA. 2008. Maximum likelihood inference of geographic range evolution by dispersal, local extinction, and cladogenesis. Systematic Biology 57:4 - 14. DOI: 10.1080/10635150701883881.

Ribas CC, Aleixo A, Nogueira AC, Miyaki CY, Cracraft J. 2011. A palaeobiogeographic model for biotic diversification within Amazonia over the past three million years. Proceedings of the Royal Society of London B: Biological Sciences 279:681 - 689. DOI: 10.1098/rspb.2011.1120.

Ronquist F, Teslenko M, Van Der Mark P, Ayres DL, Darling A, Höhna S, Larget B, Liu L, Suchard MA, Huelsenbeck JP. 2012. MrBayes 3.2: efficient Bayesian phylogenetic inference and model choice across a large model space. Systematic Biology 61:539 - 542. DOI: 10.1093/sysbio/sys029.

Rossetti DF, Cohen MC, Tatumi SH, Sawakuchi AO, Cremon EH, Mittani JC, Bertani TC, Munita CJ, Tudela DR, Yee M, Moya G. 2015. Mid-Late Pleistocene OSL chronology in western Amazonia and implications for the transcontinental Amazon pathway. Sedimentary Geology 330:1 - 15. DOI: 10.1016/j.sedgeo.2015.10.001.

Santos JC, Coloma LA, Summers K, Caldwell JP, Ree R, Cannatella DC. 2009. Amazonian amphibian diversity is primarily derived from late Miocene Andean lineages. PLoS Biology 7: e1000056. DOI: 10.1371/journal.pbio.1000056. 
736

737

738

739

740

741

742

743

744

745

746

747

748

749

750

751

752

753

754

755

756

757

758

759

760

761

762

763

764

765

766

767

768

769

770

771

772

773

774

775

776

777

778

779

780

781

Sauquet $\mathrm{H}, \mathrm{Ho}$ SY, Gandolfo MA, Jordan GJ, Wilf P, Cantrill DJ, Bayly MJ, Bromham, L, Brown GK, Carpenter RJ, Lee DM, Murphy DJ, Sniderman JMK, Udovicic F. 2012. Testing the Impact of Calibration on Molecular Divergence Times Using a Fossil-Rich Group: The Case of Nothofagus (Fagales). Systematic Biology 61:289 313. DOI: $10.1093 /$ sysbio/syr116.

Schenk JJ. 2016. Consequences of secondary calibrations on divergence time estimates. PLoS One 11:e0148228. DOI: 10.1371/journal.pone.0148228.

Schliep K. 2011. Phangorn: phylogenetic analysis in R. Bioinformatics 27:592 593. DOI: $10.1093 /$ bioinformatics/btq706.

Shephard G, Muller R, Liu L, Gurnis M. 2010. Miocene drainage reversal of the Amazon River driven by plate-mantle interaction. Nature Geoscience 3:870 - 875. DOI: 10.1038/ngeo1017.

Silva JMC, Novaes FC, Oren DC. 2002. Differentiation of Xyphocolaptes (Dendrocolaptidae) across the river Xingu, Brazilian Amazonia: Recognition of a new phylogenetic species and biogeographic implications. Bulletin of the British Ornithologists' Club 122:185 - 194.

Smith AB, Peterson KJ. 2002. Dating the time of origin of major clades: molecular clocks and the fossil record. Annual Review of Earth and Planetary Sciences 30:65 - 88. DOI: 10.1146/annurev.earth.30.091201.140057.

Smith BT, McCormack JE, Cuervo AM, Hickerson MK, Aleixo A, Cadena CD, Pérez-Emán J, Burney CW, Xie X, Harvey MG, Faircloth BC, Glenn TC, Derryberry EP, Prejean J, Fields S, Brumfield RT. 2014. The drivers of tropical speciation. Nature 515:406 - 409. DOI: 10.1038/nature13687.

Sytsma KJ, Spalink D, Berger B. 2014. Calibrated chronograms, fossils, outgroup relationships, and root priors: re-examining the historical biogeography of Geraniales. Biological Journal of the Linnean Society 113:29 - 49. DOI: 10.1111/bij.12297.

Vacher JP, Chave J, Ficetola FG, Sommeria-Klein G, Tao S, Thébaud C, Blanc M, Camacho A, Cassimiro J, Colston TJ, Dewynter M, Ernst R, Gaucher P, Gomes Jo, Jairam R, Kok PJR, Lima JD, Martinez Q, Marty C, Noonan BP, Sales-Nunes PM, Ouboter P, Recoder R, Rodrigues MT, Snyder A, Marques-Souza S, Fouquet A. 2019. Large-scale DNA-based survey of frogs in Amazonia suggest a vast underestimation of species richness and endemism. Journal of Biogeography 00:1 - 11. DOI: 10.1111/jbi.13847.

Van Soelen EE, Kim JH, Santos RV, Dantas EL, de Almeida FV, Pires JP, Roddaz M, Damsté JSS. 2017. A 30 Ma history of the Amazon River inferred from terrigenous sediments and organic matter on the Ceará Rise. Earth and Planetary Science Letters 474:40 - 48. DOI: 10.1016/j.epsI.2017.06.025.

Wallace AR. 1852. On the Monkeys of the Amazon. Journal of Natural History 14:451 - 454 .

Wesselingh FP, Räsänen ME, Irion G, Vonhof HB, Kaandorp R, Renema W, Pittman LR, Gingras M. 2002. Lake Pebas: a palaeoecological reconstruction of a Miocene, long-lived lake complex in western Amazonia. Cainozoic Research 1:35 - 68.

Wesselingh FP, Guerrero J, Räsänen ME, Romero PL, Vonhof HB. 2006. Landscape evolution and depositional processes in the Miocene Pebas lake/wetland system: evidence from exploratory boreholes in northeastern Peru. Scripta Geologica $133: 323-361$. 
782 Westerhold T, Marwan N, Drury AJ, Liebrand D, Agnini C, Anagnostou E, Barnet 783 JSK, Bohaty SM, De Vleeschouwer D, Florindo F, Frederichs T, Hodell DA, Holbourn 784 AE, Kroon D, Lauretano V, Litter K, Lourens LJ, Lyle M, Pälike H, Röhl U, Tian J, 785 Wilkens RH, Wilson PA, Zachos JC. 2020. An astronomically dated record of Earth's 786 climate and its predictability over the last 66 million years. Science 369:1383-1387. 787 DOi:10.1126/science.aba6853

788 Yang Z, Rannala B. 2006. Bayesian estimation of species divergence times under a 789 molecular clock using multiple fossil calibrations with soft bounds. Molecular biology and 790 791 792 793 evolution 23:212 - 226. DOI: $10.1093 / \mathrm{molbev} / \mathrm{msj} 024$.

Zhang C, Stadler T, Klopfstein S, Heath TA. Ronquist F. 2016. Total-evidence dating under the fossilized birth-death process. Systematic Biology 65:228 - 249. DOI:

794 10.1093/sysbio/syv080. 
Figure 1

Figure 1. Infinite-sites plot for all taxa under lognormal and exponential distributions.

The $x$-axis is the posterior means of each node age, and the $y$-axis is the $95 \%$ posterior confidence interval $(\mathrm{Cl})$ width values. The slope $(\mathrm{w})$ is a measure of fossil precision and represents the direct relationship between divergence time and uncertainty in the posterior Cl (Yang \&; Rannala 2006).

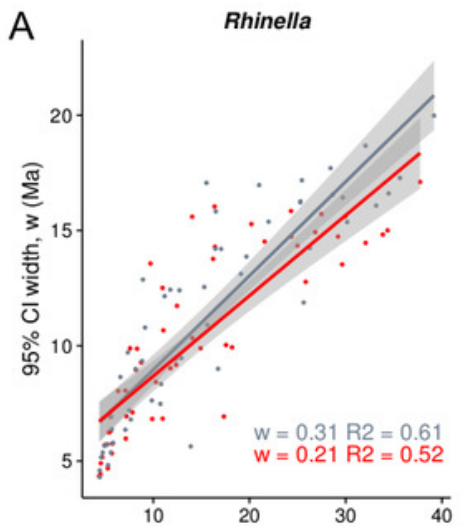

Mean posterior divergence time, $\mathrm{t}(\mathrm{Ma})$

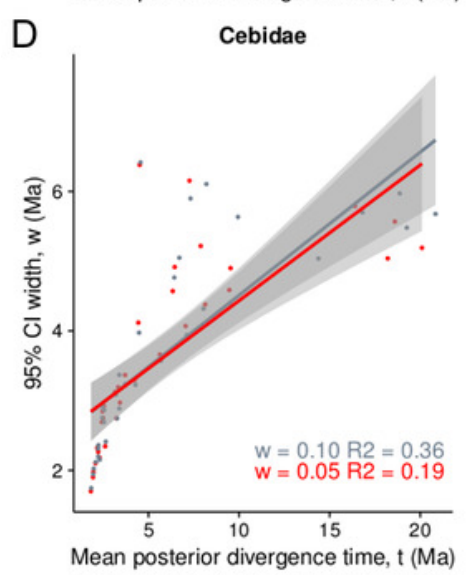

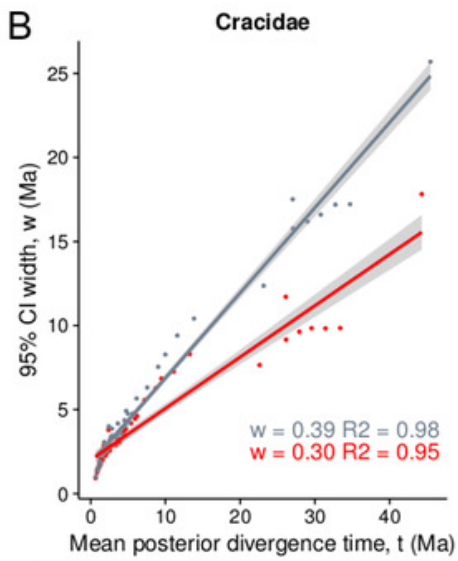

E
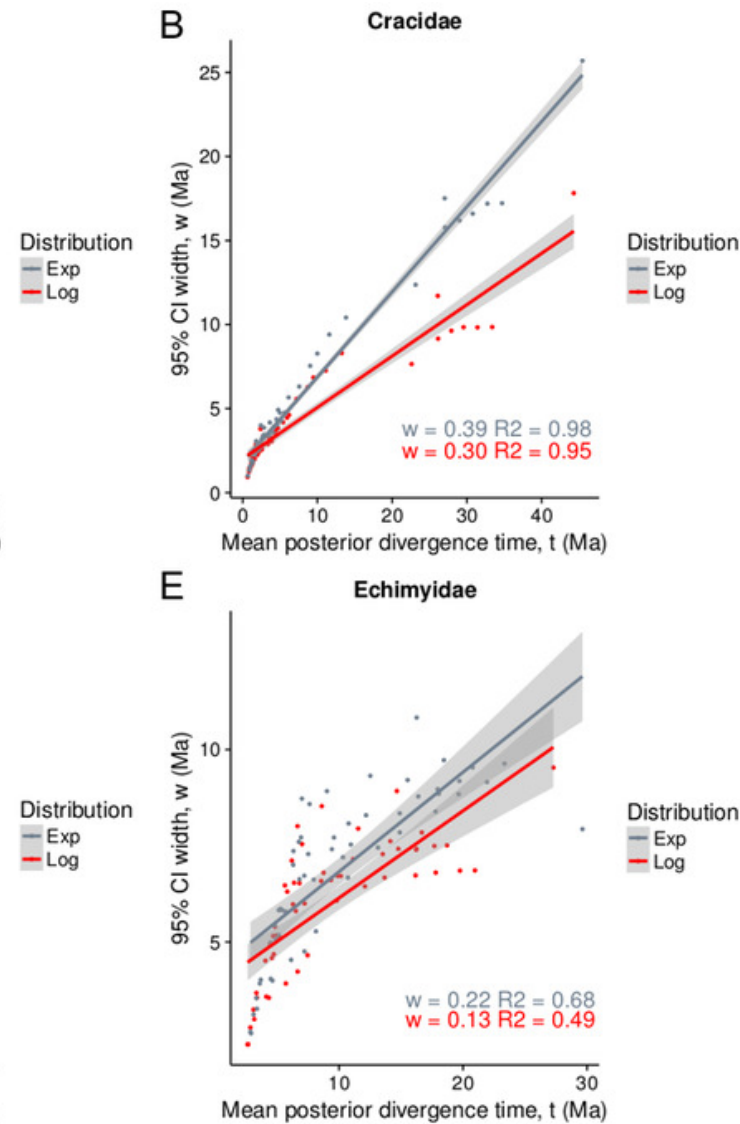

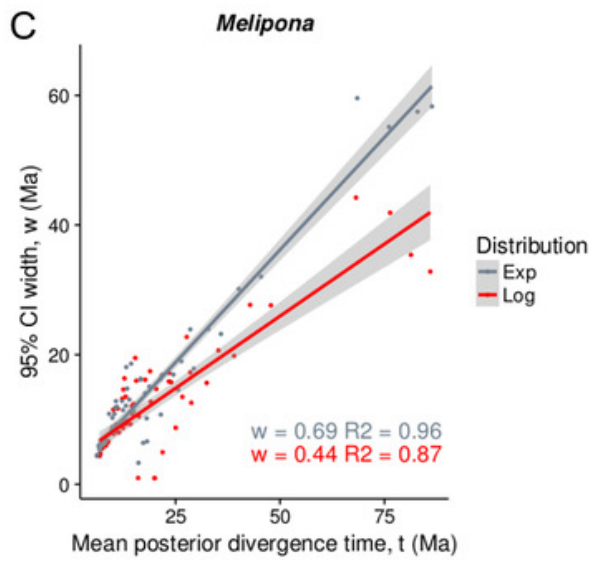

$\mathrm{F}$

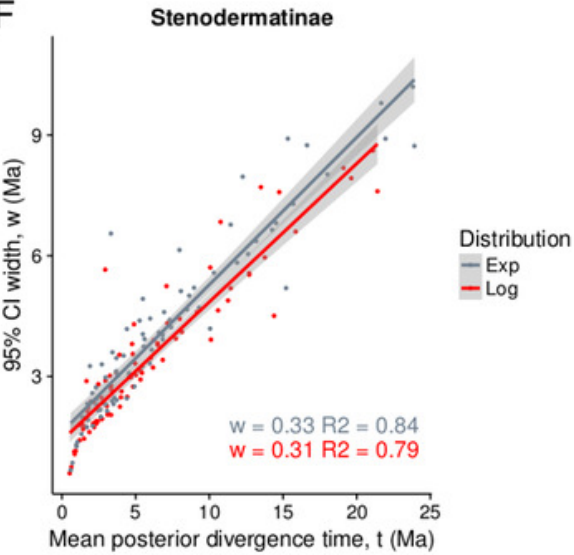


Figure 2

Figure 2. Prior age distributions and posterior age estimation for all the fossils used.

Red bars indicate the $95 \%$ posterior Confidence Interval (Cl) under a lognormal distribution, and the points represent the posterior median values. Blue bars correspond to the temporal range for each prior.
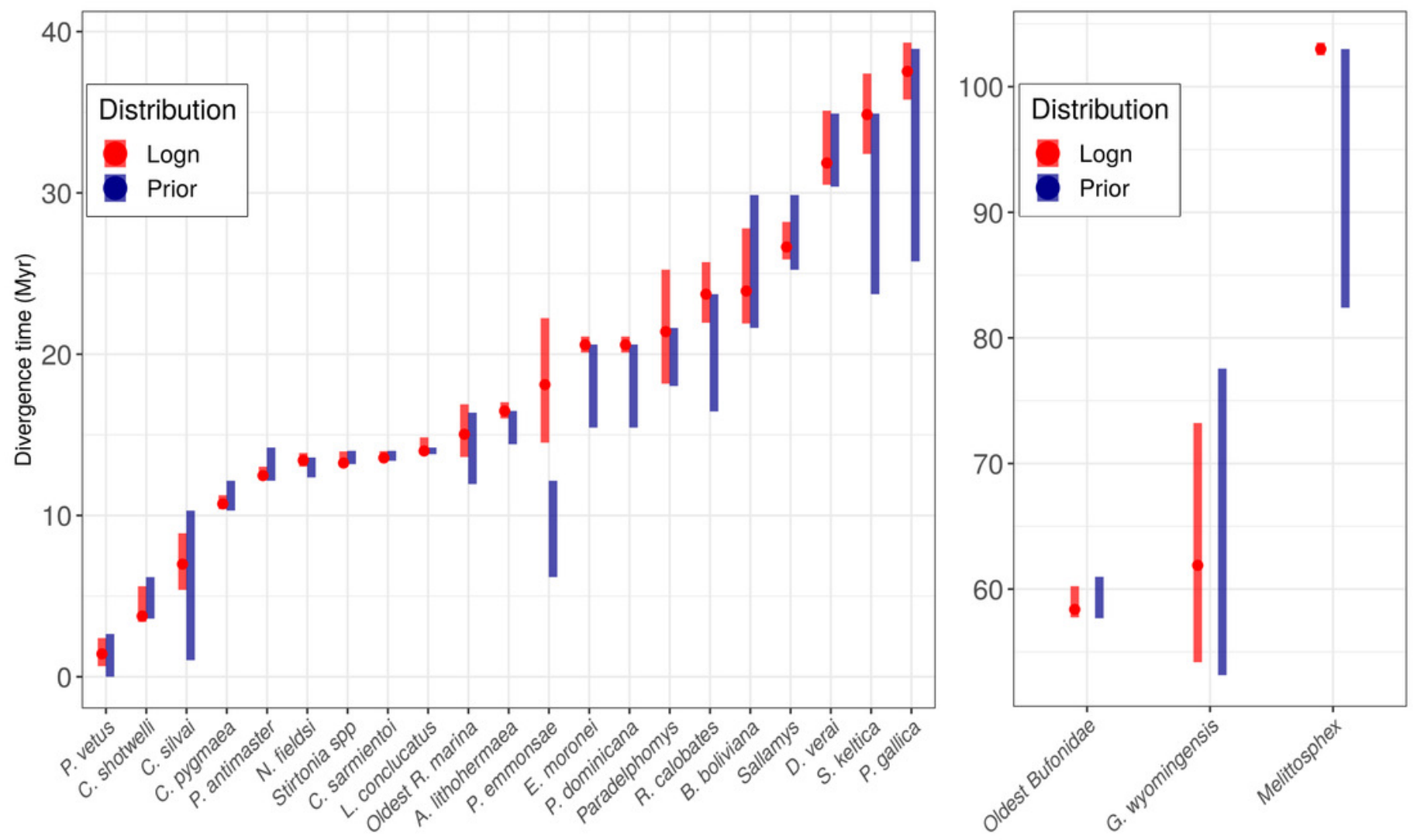


\section{Figure 3}

Figure 3. Ancestral Range Reconstruction under the model with the smallest likelihood value.

Melipona (A), Echimyidae (B), Rhinella (C), Cracidae (D), Stenodermatinae (E), and Cebidae (F). For Cracidae, Stenodermatinae, and Echimyidae the model has intermediate dispersal rates between 11.8 - 2.5 Ma (Million years ago) and maximal after 2.5 Ma, and for the rest of the taxa the non-stratified model. Area $Y^{*}=$ Araguaia+Xingu+Tocantins+Rondônia. 

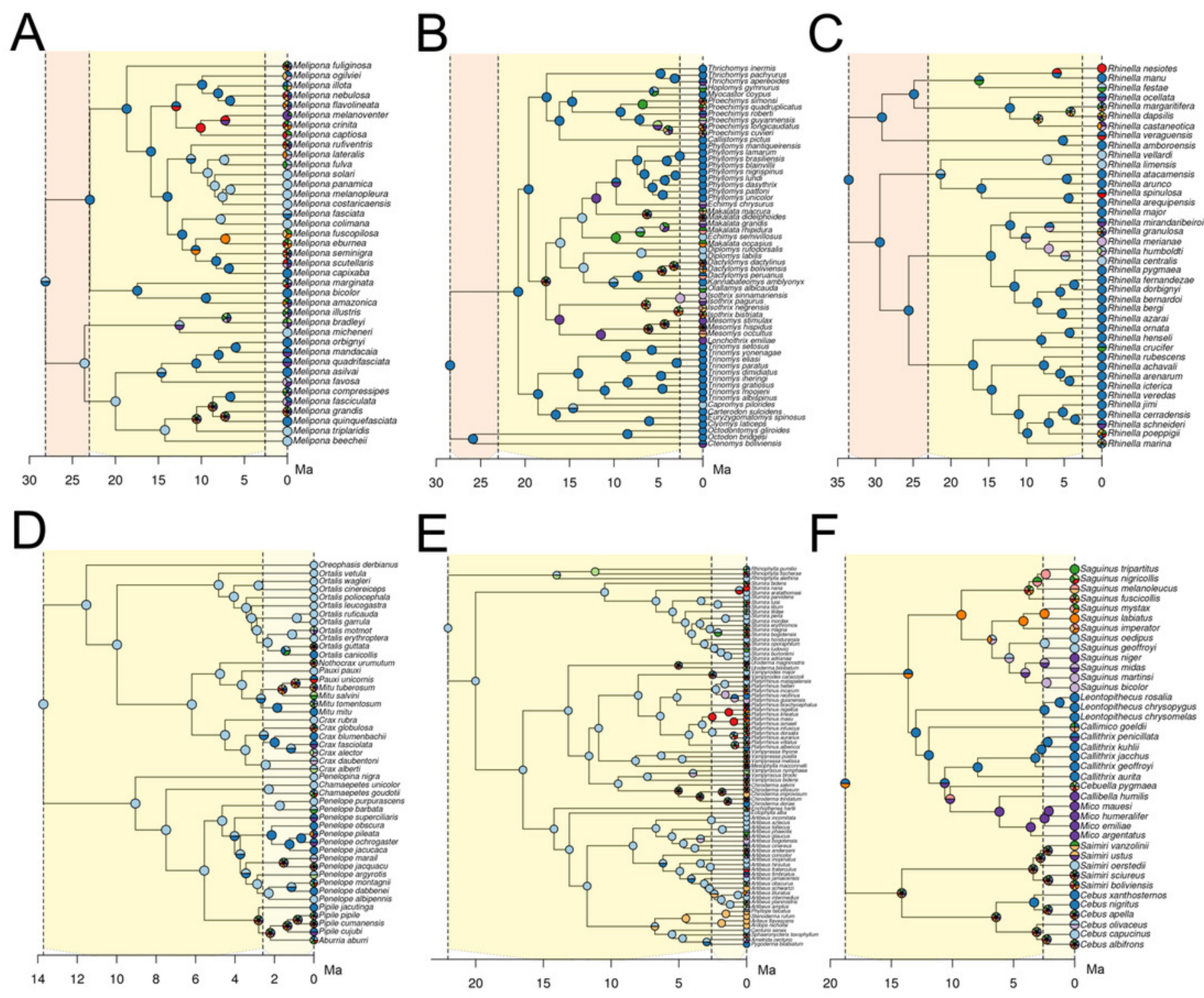

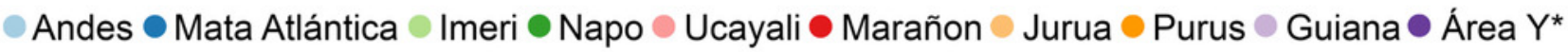
$\square$ Paleogene $\square$ Neogene $\square$ Quaternary 
Figure 4

Figure 4. RASE results.

Ancestral ranges for the six studied taxa at four time slices of interest for the "Old Amazon" and "Young Amazon" models. In blue, the PMWS through time, according to Hoorn et al. (2010) and Jaramillo et al. (2017). 


\section{Cebidae}

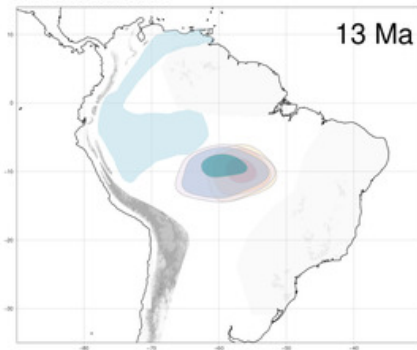

\section{Cracidae}

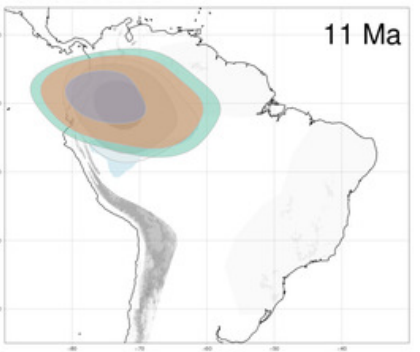

\section{Echimyidae}

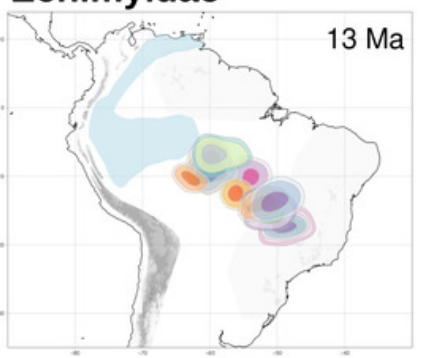

\section{Melipona}

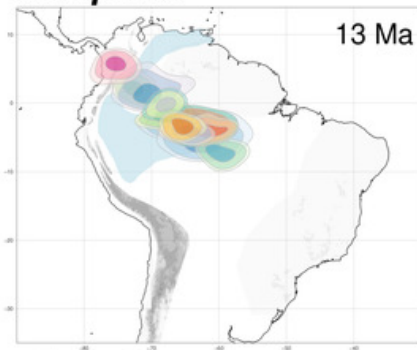

\section{Rhinella}

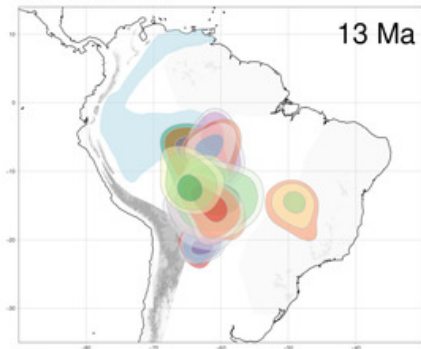

\section{Stenodermatinae}

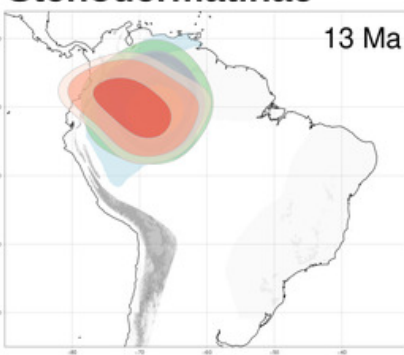

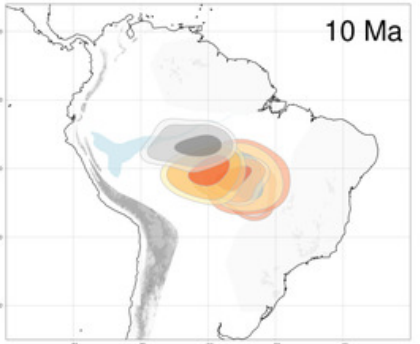
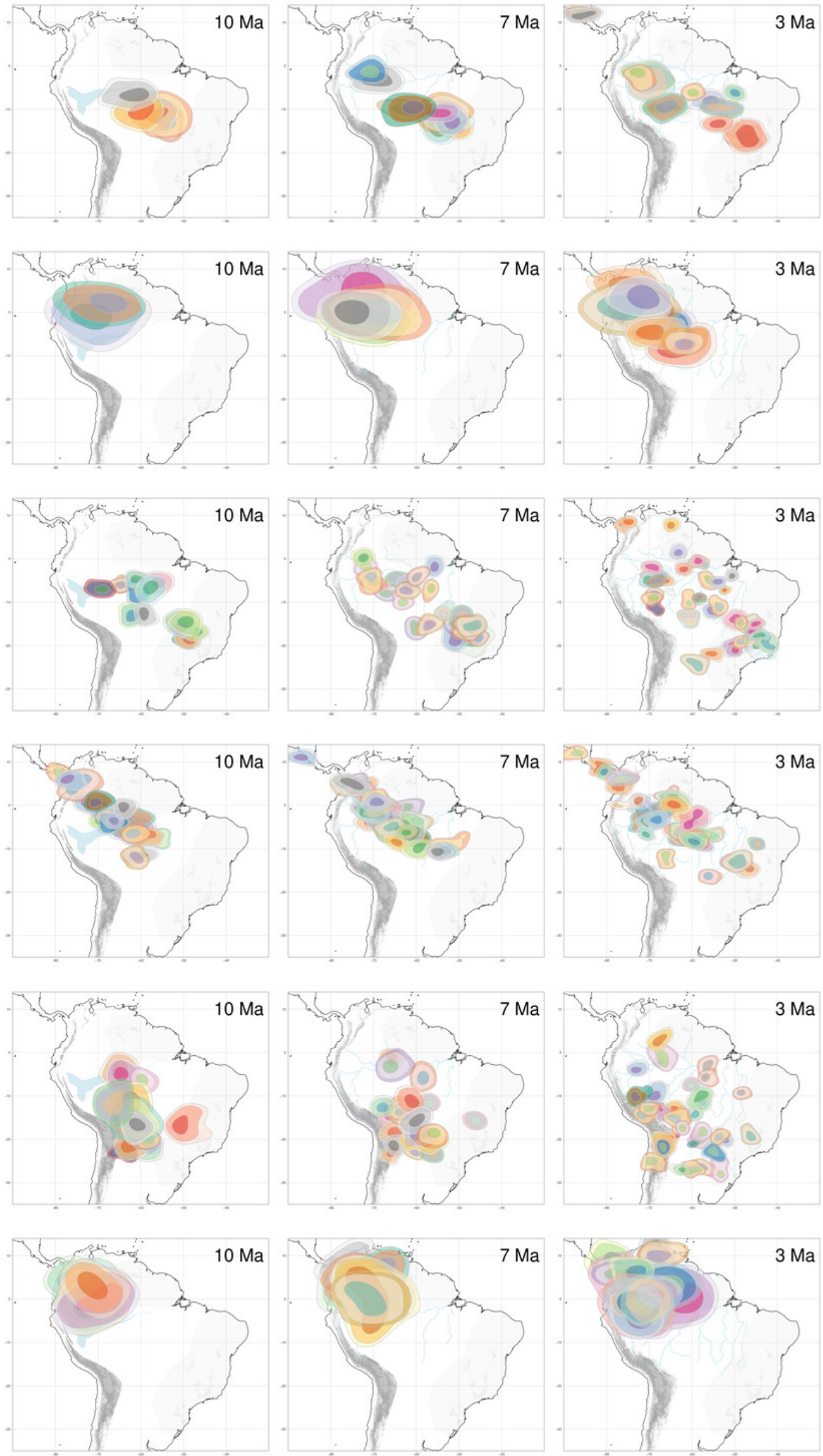

$7 \mathrm{Ma}$

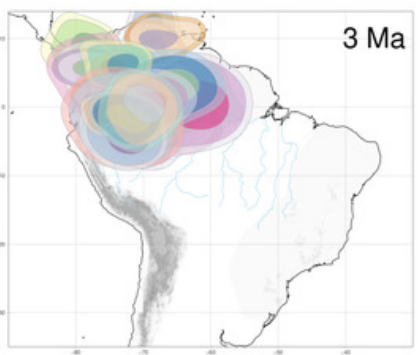




\section{Figure 5}

Figure 5. Isolation barriers and events.

Rivers found to be, probably, biogeographical barriers (dashed line) as determined under Hovenkamps's context $(1997,2001)$ for the following taxa: (A-C) Cebidae, (D) Cracidae, (E) Echimyidae, (F-G) Melipona and (H-I) Rhinella. All events were found with BioGeoBEARS, and also it is stated if the event was recovered by GEM, VIP or both.
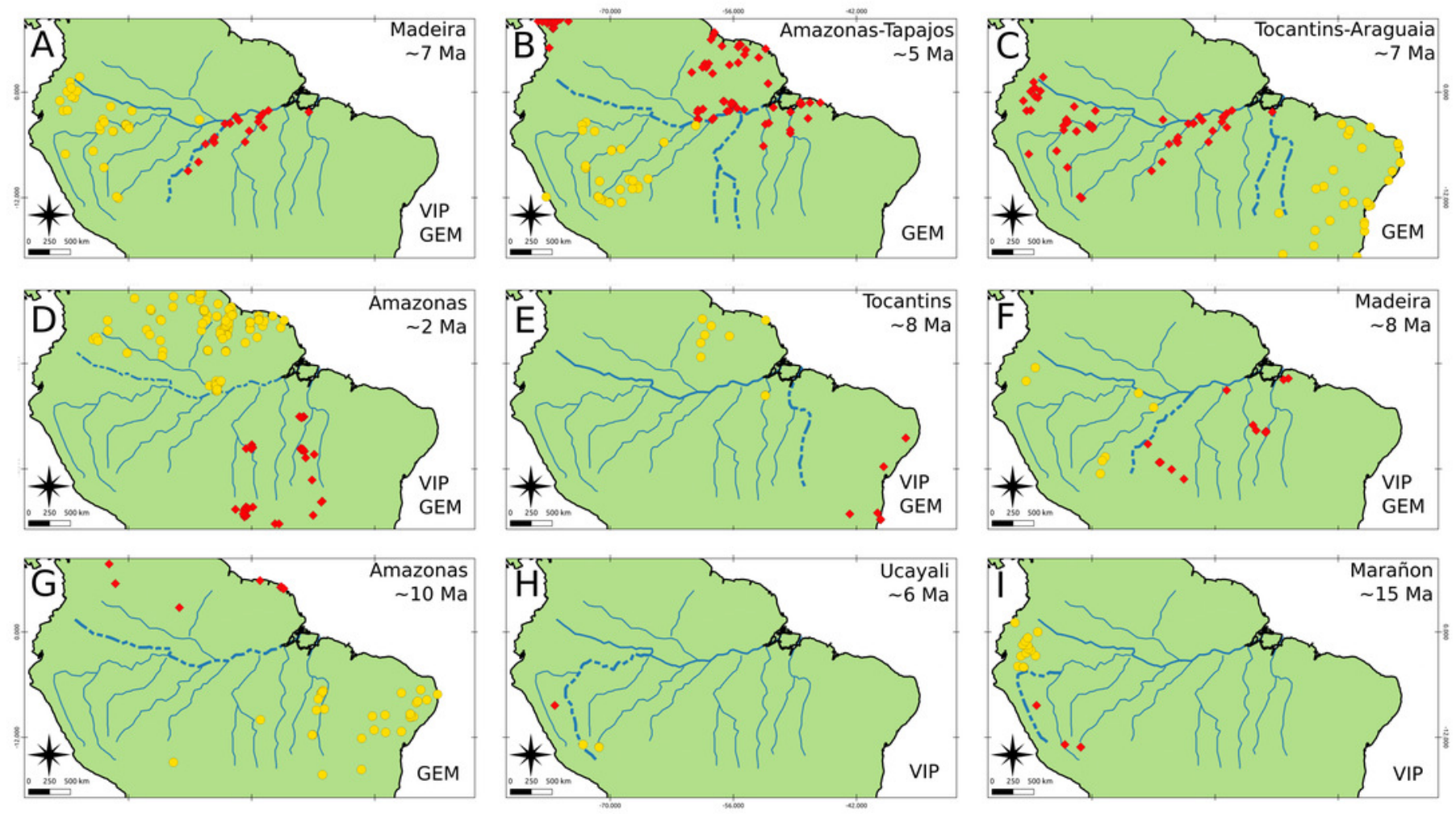


\section{Figure 6}

Figure 6. The biogeographical pattern for formation of the Amazon basin.

Maps are modified from Hoorn et al. (2010). Dates for the closure of the Panama isthmus according to Bacon et al., (2015), Caribbean islands according to Ali (2012). The numbers in the bottom right correspond to Andean uplift according to Hoorn et al. (2010). The panels (A) and (B) correspond to the temporal events proposed by Hoorn et al. (2017) for the transcontinental rivers and the establishment of the Amazon fluvial system, respectively. The panels (C) and (D) present our interpretation of the temporal events found in the present study, in which the first dispersals occur to Western Amazonia (Napo, Marañón, and Ucayali) and the expansion of the distributional range from Western Amazonia to Eastern Amazonia. Area labels as follows: Guiana (G), Imeri (I), Rondônia (R), Tapajos (T), Belem (B), Mata Atlantica (F), Xingu (X), Napo (N), Marañon (M), Ucayali (U), Jurua (J), Purus (P), Araguaia (A), Andes (D), Y Area $=$ Araguaia+Xingu+Tocantins+Rondônia. Panel $\mathrm{C}$ is only a graphical representation of the retraction of PEBAS and the formation of the Amazon rivers. 


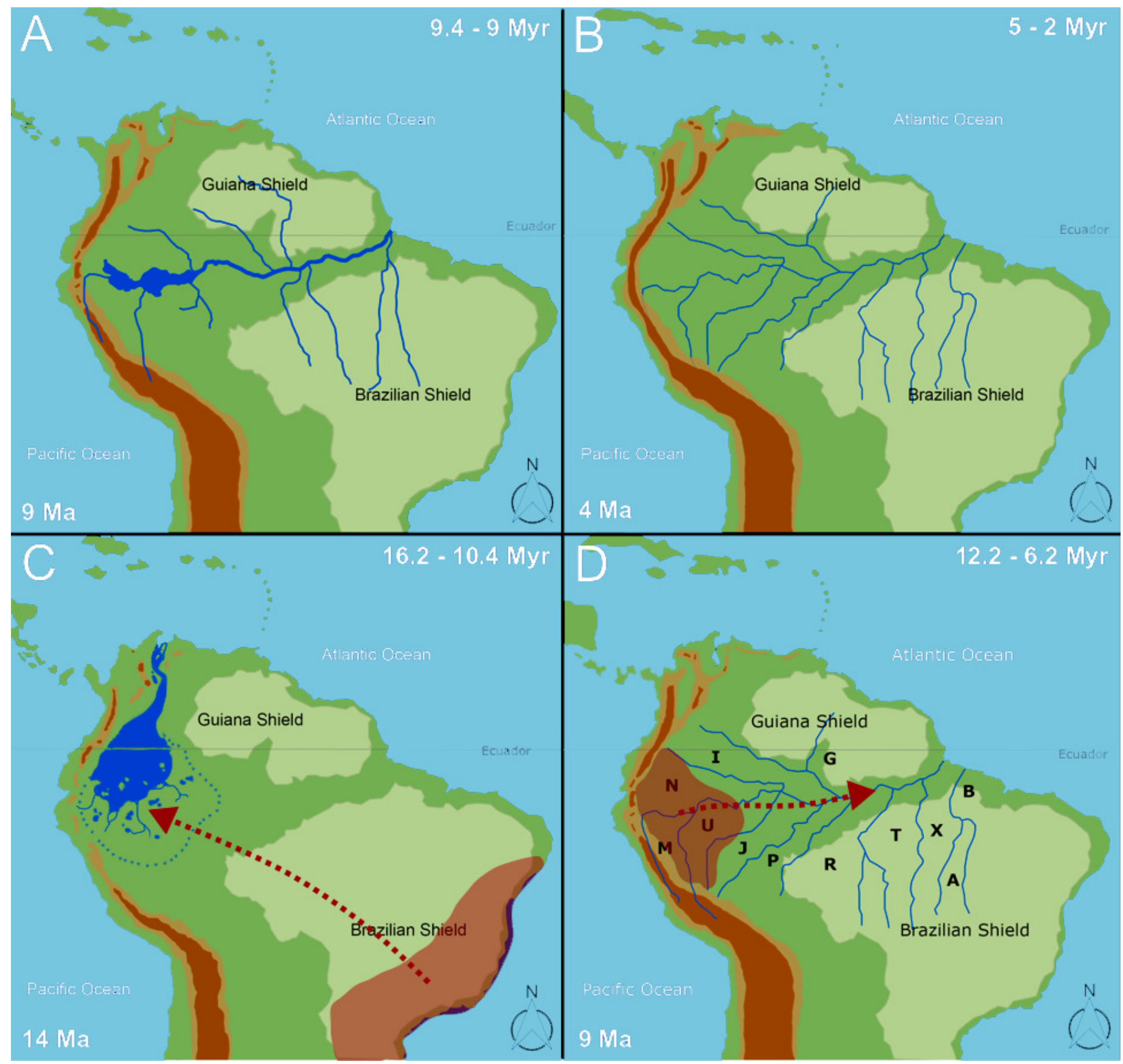




\section{Table 1 (on next page)}

Groups used in the phylogenetic reconstructions.

The number of species used for each group, the percentage of those species that ocurrs in the Amazon basin and the calibration points used. 
1 Table 1. Groups used in the phylogenetic reconstructions.

2 The number of species used for each group, the percentage of those species that ocurrs in the 3 Amazon basin and the calibration points used.

4

\begin{tabular}{|l|c|c|c|}
\hline & $\begin{array}{c}\text { Species in the } \\
\text { phylogeny }\end{array}$ & $\begin{array}{c}\text { Distributed in the } \\
\text { Amazon basin }\end{array}$ & Calibration points \\
\hline $\begin{array}{l}\text { Rhinella } \\
\text { Fitzinger, 1826 }\end{array}$ & 41 & $37 \%$ & 2 \\
\hline $\begin{array}{l}\text { Melipona } \\
\text { Illiger, 1806 }\end{array}$ & 39 & $61 \%$ & 5 \\
\hline $\begin{array}{l}\text { Cracidae } \\
\text { Vigors, 1825 }\end{array}$ & 47 & $53 \%$ & 6 \\
\hline $\begin{array}{l}\text { Cebidae } \\
\text { Bonaparte, 1831 }\end{array}$ & 44 & $59 \%$ & 4 \\
\hline $\begin{array}{l}\text { Echimyidae } \\
\text { Gray, 1825 }\end{array}$ & 58 & $43 \%$ & 3 \\
\hline $\begin{array}{l}\text { Stenodermatinae } \\
\text { Gervais, 1856 }\end{array}$ & 78 & $49 \%$ & 6 \\
\hline
\end{tabular}

5 